\title{
Effects of Fluoride and Dissolved Oxygen Concentrations on the Corrosion Behavior of Pure Titanium and Titanium Alloys
}

\author{
Masaharu NAKAGAWA, Shigeki MATSUYA and Koichi UDOH \\ Section of Biomaterials Engineering, Division of Oral Rehabilitation, \\ Faculty of Dental Science, Kyushu University \\ 3-1-1 Maidashi, Higashi-ku, Fukuoka, 812-8582, Japan
}

Received January 8, 2002/Accepted March 26, 2002

\begin{abstract}
The effects of dissolved-oxygen concentration and fluoride concentration on the corrosion behaviors of commercial pure titanium, Ti-6Al-4V and Ti-6Al-7Nb alloys and experimentally produced $\mathrm{Ti}-0.2 \mathrm{Pd}$ and $\mathrm{Ti}-0.5 \mathrm{Pt}$ alloys were examined using the corrosion potential measurements. The amount of dissolved Ti was analyzed by inductively coupled plasma mass spectroscopy. A decrease in the dissolved-oxygen concentration tended to reduce the corrosion resistance of $\mathrm{Ti}$ and $\mathrm{Ti}$ alloys. If there was no fluoride, however, corrosion did not occur. Under low dissolved-oxygen conditions, the corrosion of pure $\mathrm{Ti}$ and $\mathrm{Ti}-6 \mathrm{Al}-4 \mathrm{~V}$ and $\mathrm{Ti}-6 \mathrm{Al}-7 \mathrm{Nb}$ alloys might easily take place in the presence of small amounts of fluoride. They were corroded by half or less of the fluoride concentrations in commercial dentifrices. The Ti-0.2Pd and Ti-0.5Pt alloys did not corrode more, even under the low dissolved-oxygen conditions and a fluoridecontaining environment, than pure $\mathrm{Ti}$ and $\mathrm{Ti}-6 \mathrm{Al}-4 \mathrm{~V}$ and $\mathrm{Ti}-6 \mathrm{Al}-7 \mathrm{Nb}$ alloys. These alloys are expected to be useful as new $\mathrm{Ti}$ alloys with high corrosion resistance in dental use.
\end{abstract}

Key words : Titanium alloy, Corrosion, Fluoride

\section{INTRODUCTION}

Recently, titanium and Ti alloys have been widely used for clinical applications such as denture bases or dental implants, because they have high corrosion resistance and biocompatibility. There is a problem that the corrosion resistance of $\mathrm{Ti}$ is decreased in the presence of fluoride, which is clinically used for the prevention of dental caries $^{1-7)}$. The corrosion of $\mathrm{Ti}$ may cause fracture of the dental implant. It was reported that the presence of fluoride promotes the corrosion cracking of pure titanium under stress ${ }^{8}$. The corrosion resistance of $\mathrm{Ti}$ depends on the passive film formed on the alloy surface. The authors have shown that the presence of fluoride causes formation of $\mathrm{HF}$ under acidic conditions and that an HF concentration of greater than $30 \mathrm{ppm}$ causes the destruction of the passive film $^{7)}$. Since the passive film on $\mathrm{Ti}$ is an oxide such as $\mathrm{TiO}_{2}$, oxygen is essential for the stability of the passive film and for regeneration of the passive film broken by some other reasons.

The oxygen concentration in the subgingival part, where the dental implant, crown or bridge are set, is much lower than the other intraoral parts exposed to the open-air. Mettraux et al. ${ }^{9)}$ measured the oxygen partial pressure $\left(\mathrm{pO}_{2}\right)$ in human periodontal pockets (subgingival). According to their results, moderately deep pockets $(5-6 \mathrm{~mm})$ had a mean $\mathrm{pO}_{2}$ of $15.0 \mathrm{mmHg}\left(\mathrm{O}_{2}=0.8 \mathrm{ppm}\right)$, whereas deep pockets (7- 
$10 \mathrm{~mm})$ showed a significantly lower $\mathrm{pO}_{2}$ of $11.6 \mathrm{mmHg}\left(\mathrm{O}_{2}=0.6 \mathrm{ppm}\right)$. It was suggested that the oxygen concentration was also low in the mucosal surface of denture bases. Therefore, there is a possibility that regeneration of the broken passive film may be delayed. The synergism of such a low-oxygen condition and the presence of fluoride may cause the corrosion of $\mathrm{Ti}$.

In view of the increasing demands for dental titanium implants or restorations, it is important to develop $\mathrm{Ti}$ alloys that can maintain high corrosion resistance in low-oxygen concentration environments and even in the presence of fluoride. The addition of elements that help stabilize passive film or promote its formation will improve the corrosion resistance of $\mathrm{Ti}$. The $\mathrm{Pt}$ as well as $\mathrm{Pd}$ is known to have an effect of promoting the formation of passive film on $\mathrm{Ti}^{10,11}$.

The purpose of the present study was to examine the effects of the dissolvedoxygen concentration and fluoride concentration on the corrosion behaviors of commercial pure $\mathrm{Ti}, \mathrm{Ti}-6 \mathrm{Al}-4 \mathrm{~V}$ and $\mathrm{Ti}-6 \mathrm{Al}-7 \mathrm{Nb}$ alloys, which are currently used in clinical dentistry. In addition, the corrosion behavior of Ti-0.2Pd alloy which has a high corrosion resistance in a fluoride-containing acidic solution ${ }^{12)}$, and $\mathrm{Ti}-0.5 \mathrm{Pt}$ alloy which is expected to have an effect of promoting the formation of a passive film, were also investigated.

\section{MATERIALS AND METHODS}

\section{Materials}

The commercially pure titanium (CP Ti, JIS grade 2), Ti-6Al-4V and Ti-6Al-7Nb alloys presently used in clinical practice and the experimental Ti-0.2Pd and Ti-0.5Pt alloys were examined in this study. Ti-0.2Pd and Ti-0.5Pt alloys were made from CP $\mathrm{Ti}$ and $99.99 \% \mathrm{Pd}$ and $99.95 \% \mathrm{Pt}$ using an argon arc casting machine (TICAST Super R., Kobelco Research Institute, Japan).

The alloy specimens $(7 \mathrm{~mm}$ square $\times 1.5 \mathrm{~mm}$ thick $)$ were embedded in epoxy resin. They were then polished to \#1,500 with waterproof grinding paper and washed in ethanol. The exposed surface areas of the specimen were 0.4 to $0.6 \mathrm{~cm}^{2}$.

\section{Test solutions}

An artificial saliva $\left(\mathrm{NaCl} 0.04 \%, \mathrm{KCl} 0.04 \%, \mathrm{CaCl}_{2} 0.795 \%, \mathrm{NaH}_{2} \mathrm{PO}_{4} 0.078 \%, \mathrm{Na}_{2} \mathrm{~S}\right.$ $0.0005 \%$, urea $0.1 \%$ ) and artificial saliva containing 0.05 to $0.5 \% \mathrm{NaF}$ were used as the test solutions. To examine the effect of dissolved oxygen concentrations, a solution exposed to air (open-air, $\mathrm{O}_{2} \geqq 8.1 \mathrm{ppm}$ ) and a solution deaerated by $\mathrm{N}_{2}$ gas bubbling (non- $\mathrm{O}_{2}, \mathrm{O}_{2} \leqq 0.1 \mathrm{ppm}$ ) were used in the immersion test. The dissolved-oxygen concentration was measured using a DO meter (TOX-90, Toko Chemical Laboratories, Japan). The temperature of the test solution was kept at $37 \pm 0.1^{\circ} \mathrm{C}$ and was stirred at $200 \mathrm{rpm}$ with a magnetic stirrer. To examine the effect of $\mathrm{pH}$ and fluoride concentration, the 0.05 to $0.5 \% \mathrm{NaF}$ solutions were also used as the test solution. The 0.05 to $0.5 \% \mathrm{NaF}$ concentrations correspond to 226 to $2,262 \mathrm{ppm}$ fluoride. The $\mathrm{pH}$ levels of $\mathrm{NaF}$ solutions were controlled within the range of $\mathrm{pH} 5.0$ to 6.5 by 
adding $\mathrm{H}_{3} \mathrm{PO}_{4}$.

\section{Corrosion test}

The counter and reference electrodes were platinum and $\mathrm{KCl}$ saturated $\mathrm{Ag} / \mathrm{AgCl}$ electrodes, respectively. The potential of this reference electrode is denoted by $\mathrm{E}(\mathrm{Ag} /$ $\mathrm{AgCl})=\mathrm{E}$ ( saturated calomel electrode: $\mathrm{SCE})+48.4 \mathrm{mV}$. Immediately after polishing the specimen, changes in the corrosion potential with immersion time were measured in the test solution for 30 min (Potentiostat HA-301, HOKUTO DENKO, Japan).

\section{Dissolved titanium analysis}

The concentrations of $\mathrm{Ti}$ dissolved in the test solution after immersion for $24 \mathrm{hrs}$ were analyzed by inductively coupled plasma mass (ICP-MS) spectroscopy (PMS 2000, YOKOGAWA, Japan). The immersion test was performed five times under the same conditions. Results were statistically analyzed by ANOVA with Scheff's test at a significance level of $1 \%$.

\section{RESULTS}

\section{Corrosion potential in artificial saliva}

Fig. 1 shows the changes in the corrosion potentials of pure $\mathrm{Ti}$ and $\mathrm{Ti}$ alloys in artificial saliva under the open-air and non- $\mathrm{O}_{2}$ conditions. The results for pure $\mathrm{Ti}$, Ti6Al-4V and Ti-6Al-7Nb alloys are shown in Fig. 1(a). Under the open-air condition, the corrosion potentials of all alloys increased and those values were greater than $0.6 \mathrm{~V}$. In contrast, when the dissolved-oxygen concentration was less than $0.1 \mathrm{ppm}$ (non- $\mathrm{O}_{2}$ ), the corrosion potential values were $0.2 \mathrm{~V}$ lower than those of the open-air conditions. Fig. 1(b) shows the results for Ti-0.2Pd and Ti-0.5Pt alloys. Changes in the corrosion potential of these alloys under the non- $\mathrm{O}_{2}$ conditions were similar to those of the open-air condition. Those values were greater than $-0.6 \mathrm{~V}$. Fig. 2 shows changes in the corrosion potentials of $\mathrm{Ti}, \mathrm{Ti}-6 \mathrm{Al}-4 \mathrm{~V}, \mathrm{Ti}-6 \mathrm{Al}-7 \mathrm{Nb}, \mathrm{Ti}-0.2 \mathrm{Pd}$ and Ti-0.5Pt alloys in an artificial saliva containing 0 to $0.5 \% \mathrm{NaF}$ ( $\mathrm{pH} 4.9$ to 6.5 ) under a dissolved-oxygen concentration of less than $0.1 \mathrm{ppm}$. When the dissolved-oxygen concentration was low and fluoride was present, the corrosion potentials of $\mathrm{Ti}$, $\mathrm{Ti}$ 6Al-4V and Ti-6Al-7Nb alloys markedly decreased as shown in Fig. 2(a), (b) and (c). The corrosion potential of $\mathrm{Ti}$ decreased to less than $-1.0 \mathrm{~V}$ by the addition of $0.2 \%$ $\mathrm{NaF}$. Those of Ti-6Al-4V and Ti-6Al-7Nb alloys decreased to less than $-1.0 \mathrm{~V}$ by the addition of $0.1 \% \mathrm{NaF}$. The decreases of the corrosion potential by the addition of $\mathrm{NaF}$ in Ti-6Al-4V and Ti-6Al-7Nb alloys were more marked than that of pure $\mathrm{Ti}$. The corrosion potentials of $\mathrm{Ti}-0.2 \mathrm{Pd}$ and $\mathrm{Ti}-0.5 \mathrm{Pt}$ alloys increased even under the low dissolved-oxygen concentration conditions as shown in Fig. 2(d). Even the addition of $0.5 \% \mathrm{NaF}$ did not decrease the corrosion potential of Ti-0.2Pd and Ti-0.5Pt alloys. Fig. 3 shows the changes in the corrosion potentials of Ti, Ti-6Al-4V, Ti-6Al-7Nb, Ti$0.2 \mathrm{Pd}$ and $\mathrm{Ti}-0.5 \mathrm{Pt}$ alloys when they were immersed in artificial saliva containing $0.2 \% \mathrm{NaF}$ under the dissolved-oxygen concentration of less than $0.1 \mathrm{ppm}$. The 

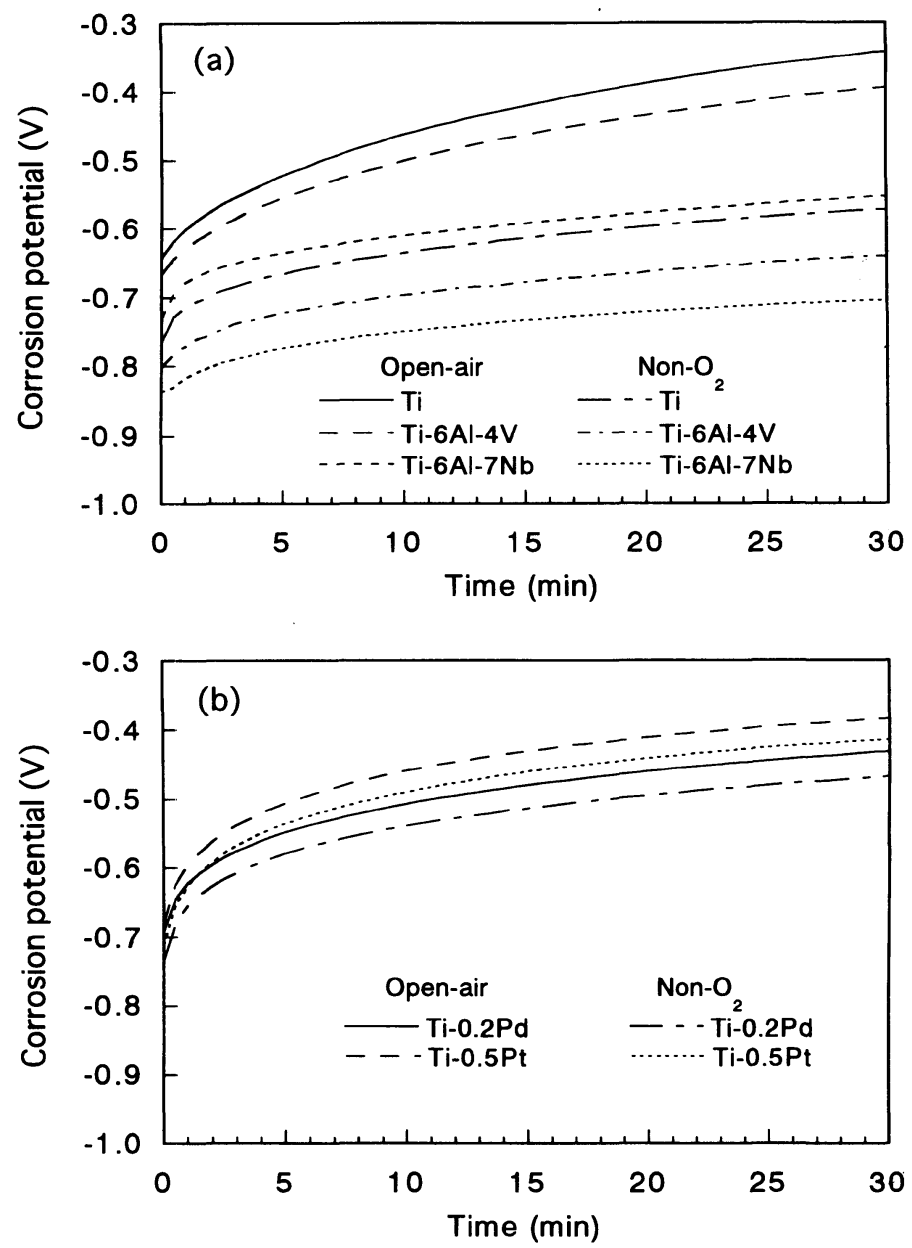

Fig. 1 Changes in the corrosion potential of (a) Ti, Ti-6Al$4 \mathrm{~V}$ and $\mathrm{Ti}-6 \mathrm{Al}-7 \mathrm{Nb}$ and (b) $\mathrm{Ti}-0.2 \mathrm{Pd}$ and $\mathrm{Ti}-0.5 \mathrm{Pt}$ with immersion time in the open-air and non- $\mathrm{O}_{2}$ artificial saliva.

corrosion potential of $\mathrm{Ti}-0.2 \mathrm{Pd}$ and $\mathrm{Ti}-0.5 \mathrm{Pt}$ alloys increased during the early stage of immersion and the final values were between -0.7 and $-0.6 \mathrm{~V}$. However, the corrosion potential of $\mathrm{Ti}$, Ti-6 Al-4V and $\mathrm{Ti}-6 \mathrm{Al}-7 \mathrm{Nb}$ alloys decreased with time immediately after immersion and the values were between -1.0 and $-1.1 \mathrm{~V}$.

\section{Immersion test in NaF solution}

To examine the effects of the fluoride concentration and $\mathrm{pH}$ under the low dissolvedoxygen concentration conditions, the changes in the corrosion potential were measured in $\mathrm{NaF}$ solution with various pHs. Fig. 4(a) shows the changes in the corrosion potential of $\mathrm{Ti}$ with immersion time in a $0.1 \% \mathrm{NaF}$ solution under the open-air 

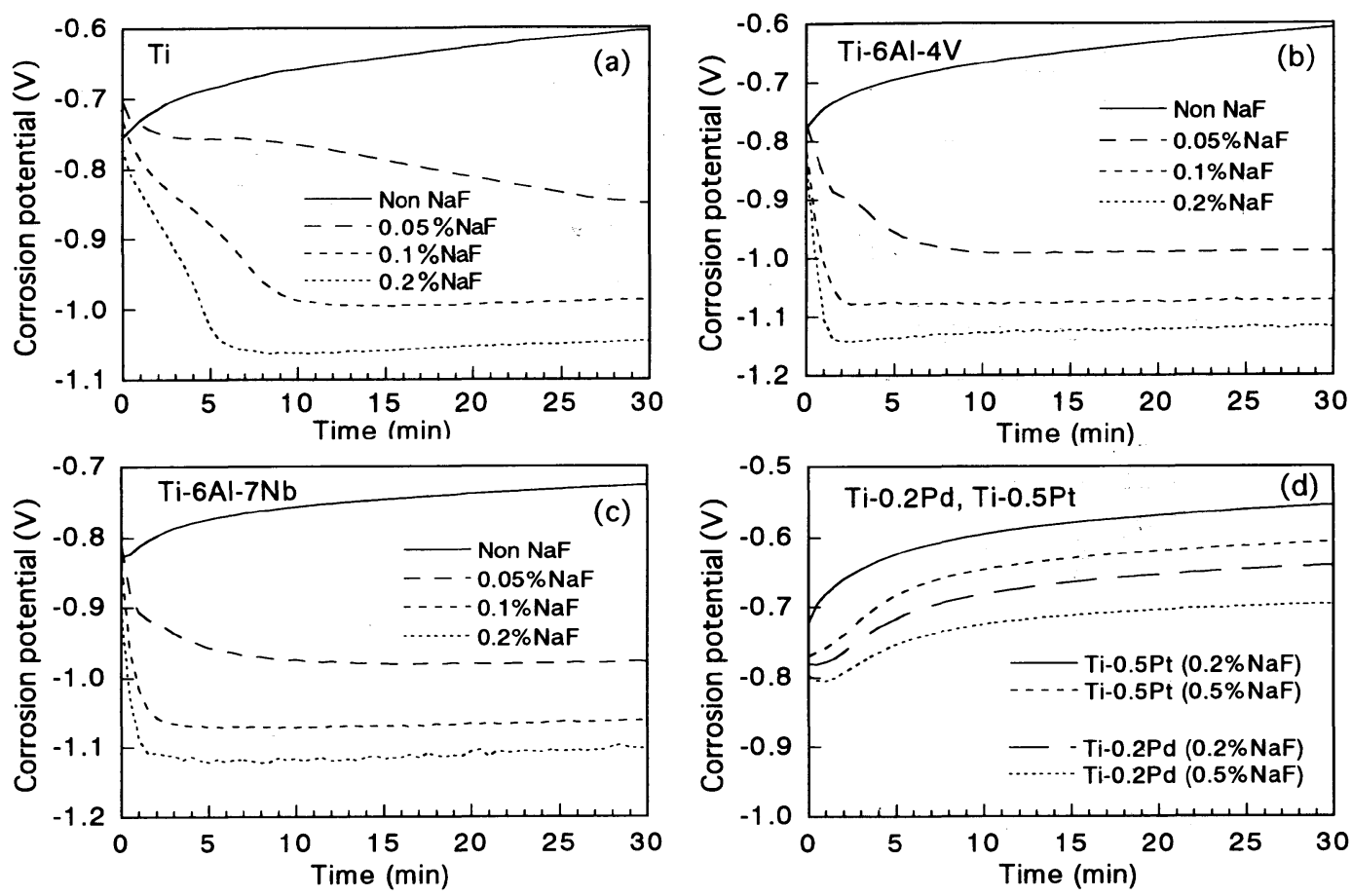

Fig. 2 Changes in the corrosion potential of (a) Ti, (b) Ti-6Al-4V, (c) Ti-6Al-7Nb and (d) Ti$0.2 \mathrm{Pd}$ and $\mathrm{Ti}-0.5 \mathrm{Pt}$ with immersion time in the non $-\mathrm{O}_{2}$ artificial saliva including various $\mathrm{NaF}$ concentrations. $\mathrm{pH}$ values: $0 \% \mathrm{NaF}(\mathrm{pH} 4.90), 0.05 \% \mathrm{NaF}(\mathrm{pH} 4.92), 0.1 \% \mathrm{NaF}(\mathrm{pH}$ $5.16), 0.2 \% \mathrm{NaF}(\mathrm{pH} 5.50), 0.5 \% \mathrm{NaF}(\mathrm{pH} 6.20)$

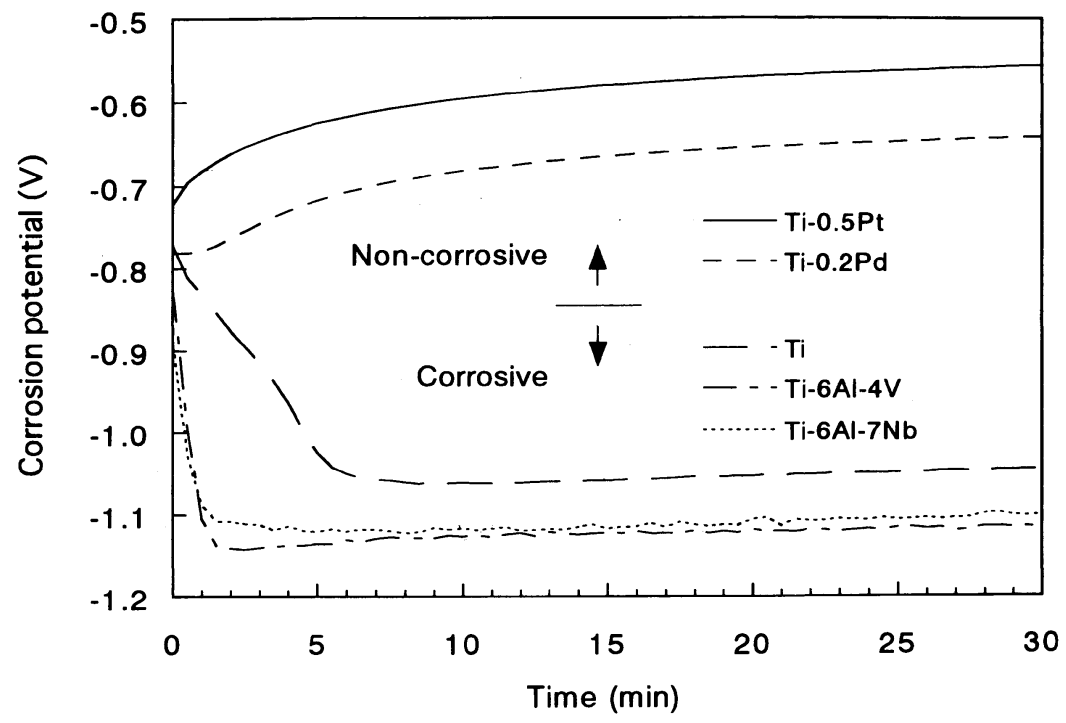

Fig. 3 Changes in the corrosion potential of $\mathrm{Ti}$ and Ti alloys with immersion time in the non- $\mathrm{O}_{2}$ artificial saliva including $0.2 \% \mathrm{NaF}$. 

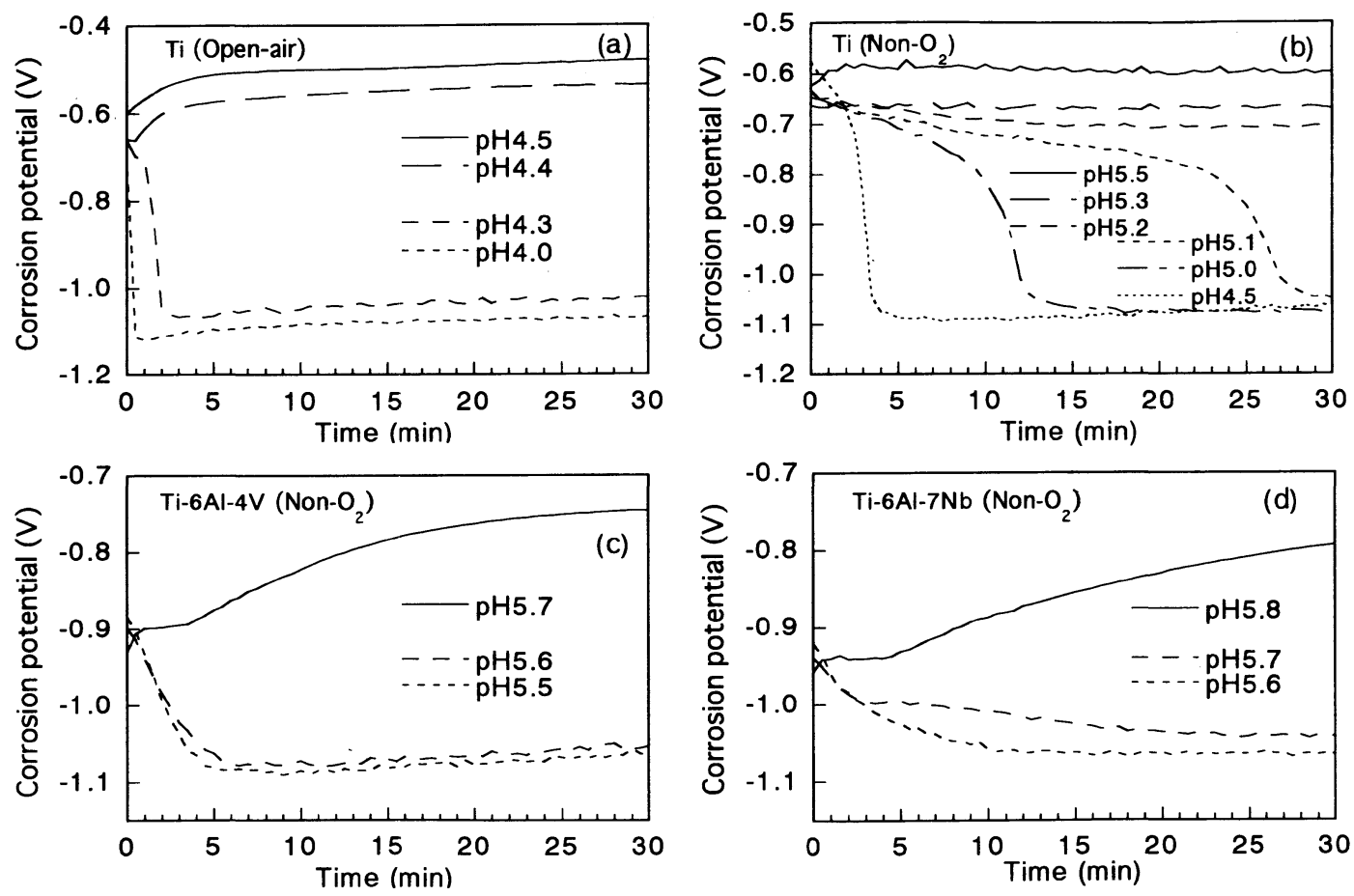

Fig. 4 Changes in the corrosion potential of $\mathrm{Ti}$ and $\mathrm{Ti}$ alloys with immersion time in the non$\mathrm{O}_{2}$ artificial saliva including $0.1 \% \mathrm{NaF}$.

conditions. There was a marked difference in the corrosion potential on both sides of the boundary between $\mathrm{pH} 4.4$ and 4.3. Similar boundaries also existed in the Ti$6 \mathrm{Al}-4 \mathrm{~V}$ and Ti-6Al-7Nb alloys under the open-air conditions ${ }^{12)}$. Fig. 4(b) shows the changes in the corrosion potential of $\mathrm{Ti}$ in $0.1 \% \mathrm{NaF}$ solution with the dissolvedoxygen concentration of less than $0.1 \mathrm{ppm}$. In the non- $\mathrm{O}_{2}$ conditions, the boundary $\mathrm{pH}$ value shifted from between $\mathrm{pH} 4.4$ and $\mathrm{pH} 4.3$ to between $\mathrm{pH} 5.2$ and 5.1. Fig. $4(\mathrm{c})$ and (d) show that similar boundaries were clearly seen in Ti-6Al-4V (between $\mathrm{pH} 5.6$ and 5.7) and Ti-6Al-7N (between $\mathrm{pH} 5.7$ and 5.8) alloys in the non- $\mathrm{O}_{2}$ conditions. Fig. 5 shows the plots of boundary $\mathrm{pH}$ values in each alloy, at which the corrosion behavior changes as mentioned above. It also shows the results of the openair conditions obtained in our previous study ${ }^{12)}$ for comparison. The boundary $\mathrm{pH}$ of the non- $\mathrm{O}_{2}$ environment shifted to the higher $\mathrm{pH}$ side compared with the open-air environment. The results of the Ti-0.5Pt and Ti-0.2Pd (non- $\mathrm{O}_{2}$ ) alloys are not included in Fig. 5 because they did not show obvious boundary pHs as seen in the pure Ti, Ti$6 \mathrm{Al}-4 \mathrm{~V}$ and $\mathrm{Ti}-6 \mathrm{Al}-7 \mathrm{Nb}$ alloys.

The amount of dissolved Ti

To compare their corrosion resistances the amount of dissolved $\mathrm{Ti}$ was measured. Fig. 6 shows the amount of dissolved Ti measured by ICP analysis after immersion 


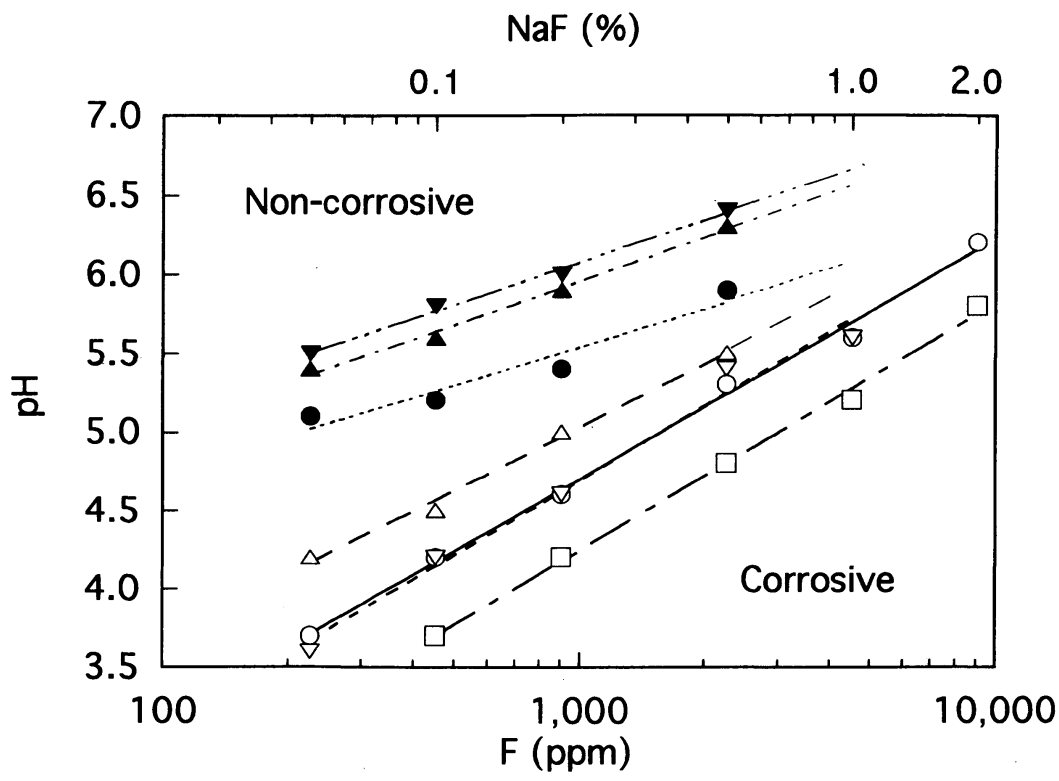

Fig. 5 Border between the non-corrosive and corrosive regions for each alloy after immersion in the non- $\mathrm{O}_{2}$ and open-air solutions for 30 $\min$.

Non- $\mathrm{O}_{2} \bigcirc \mathrm{Ti}, \boldsymbol{\Delta}: \mathrm{Ti}-6 \mathrm{Al}-4 \mathrm{~V}, \boldsymbol{\nabla}: \mathrm{Ti}-6 \mathrm{Al}-7 \mathrm{Nb}$

Open-air $\bigcirc:$ Ti, $\triangle$ : Ti-6Al-4V, $\nabla:$ Ti-6Al-7Nb, $\square:$ Ti-0.2Pd

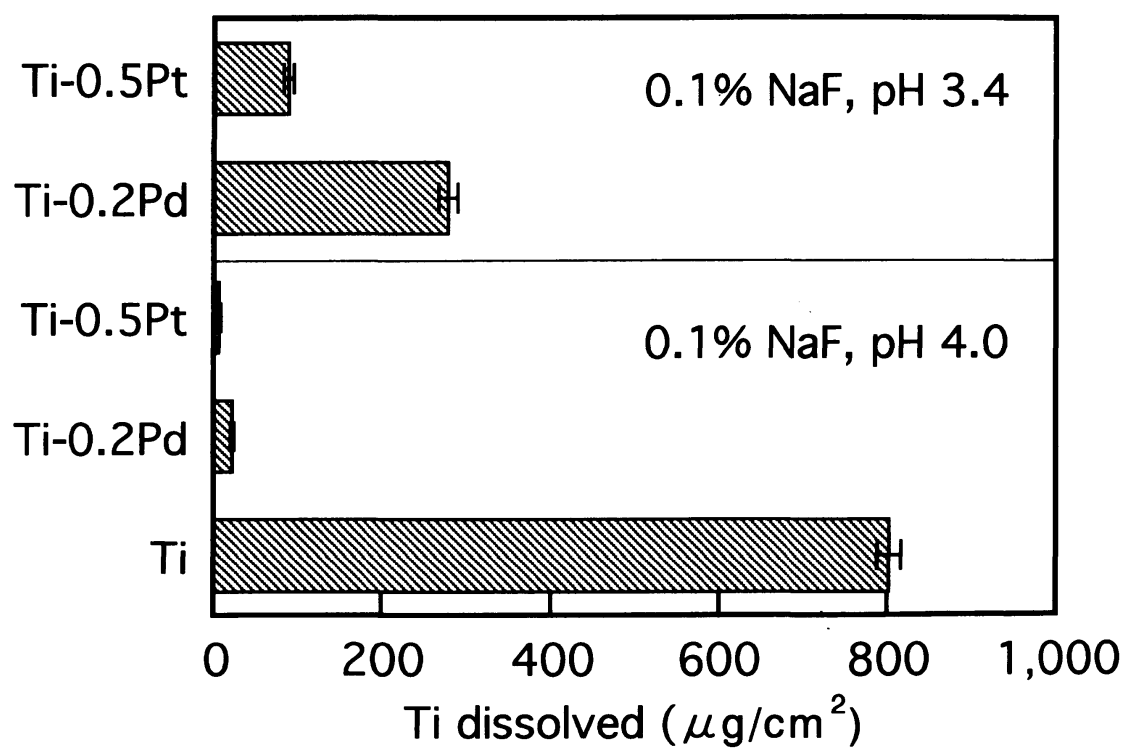

Fig. 6 The amount of $\mathrm{Ti}$ dissolved after $24 \mathrm{hr}$ immersion in the open-air $0.1 \% \mathrm{NaF}$ solutions. 
for $24 \mathrm{hrs}$ in a $0.1 \% \mathrm{NaF}$ solution at $\mathrm{pH} 4.0$ under the open-air environment. At $\mathrm{pH}$ 4.0 , the amount of $\mathrm{Ti}$ dissolved in the $\mathrm{Ti}-0.2 \mathrm{Pd}$ and $\mathrm{Ti}-0.5 \mathrm{Pt}$ alloys were 22.0 and 6 . $1 \mu \mathrm{g} / \mathrm{cm}^{2}$, respectively, and were significantly $(\mathrm{p}<0.01)$ smaller than that of $\mathrm{Ti}$ (802. $\left.1 \mu \mathrm{g} / \mathrm{cm}^{2}\right)$. At pH 3.4, the amount of $\mathrm{Ti}$ dissolved in the Ti-0.2Pd and Ti-0.5Pt alloys were 278.2 and $88.9 \mu \mathrm{g} / \mathrm{cm}^{2}$, respectively.

\section{DISCUSSION}

In this study, corrosion resistance was evaluated from corrosion potential values. A higher corrosion potential corresponded to a higher corrosion resistance and a corrosion potential below $-1.0 \mathrm{~V}$ meant corrosive in our previous studies ${ }^{7,12)}$. In the openair artificial saliva, the corrosion potentials of $\mathrm{Ti}$, and the $\mathrm{Ti}-6 \mathrm{Al}-4 \mathrm{~V}$ and $\mathrm{Ti}-6 \mathrm{Al}-7 \mathrm{Nb}$ alloys increased and the final values were about $-0.4 \mathrm{~V}$ as shown in Fig. 1(a). This suggests that they maintain a good corrosion resistance. In contrast, when the dissolved-oxygen concentration was less than $0.1 \mathrm{ppm}$ (non- $\left.\mathrm{O}_{2}\right)$, the corrosion potential values were above $0.2 \mathrm{~V}$, which was lower than those of the open-air conditions. However, the corrosion potential values were not less than $-0.8 \mathrm{~V}$ and increased with immersion time. This suggests that the corrosion did not occur. This result suggests that a decrease in the dissolved-oxygen concentration does not cause the corrosion of $\mathrm{Ti}$ but can decrease the corrosion resistance. In the non- $\mathrm{O}_{2}$ artificial saliva, the corrosion potentials of the $\mathrm{Ti}-0.2 \mathrm{Pd}$ and $\mathrm{Ti}-0.5 \mathrm{Pt}$ alloys increased and the values were similar to those of the open-air condition (Fig. 1(b)). This means that these alloys maintained their high corrosion resistances even under the low dissolvedoxygen concentration conditions.

The corrosion of $\mathrm{Ti}$ did not take place only in the low dissolved-oxygen condition. However, it is expected that the corrosion will be accelerated in the presence of fluoride. The corrosion potentials of $\mathrm{Ti}$, and the $\mathrm{Ti}-6 \mathrm{Al}-4 \mathrm{~V}$ and $\mathrm{Ti}-6 \mathrm{Al}-7 \mathrm{Nb}$ alloys decreased in the non- $\mathrm{O}_{2}$ artificial saliva containing $\mathrm{NaF}$ by greater than $0.05 \%$ (Fig. $2(\mathrm{a})$, (b) and (c)). This suggests that a small amount of fluoride can cause corrosion of the Ti-6Al-4V and Ti-6Al-7Nb alloys, if they are under low dissolved-oxygen conditions. Even by the addition of $0.1 \% \mathrm{NaF}$, the corrosion potential values were lower than $-1.0 \mathrm{~V}$, that is, the corrosion of $\mathrm{Ti}$ occurred. The corrosion potentials of the $\mathrm{Ti}-0.2 \mathrm{Pd}$ and $\mathrm{Ti}-0.5 \mathrm{Pt}$ alloys, however, increased in the non- $\mathrm{O}_{2}$ artificial saliva containing $0.5 \% \mathrm{NaF}$. This shows that these alloys do not corrode and they maintain high corrosion resistances, even under conditions at which the corrosion of pure $\mathrm{Ti}$, and the Ti-6Al-4V and Ti-6Al-7Nb alloys occurs. Since $0.1 \% \mathrm{NaF}$ contains 453 ppm fluoride, this result suggests that $\mathrm{Ti}$, and the $\mathrm{Ti}-6 \mathrm{Al}-4 \mathrm{~V}$ and $\mathrm{Ti}-6 \mathrm{Al}-7 \mathrm{Nb}$ alloys can be corroded by half the fluoride concentrations that are contained in commercial dentifrices. Fig. 3 shows the changes in the corrosion potential of $\mathrm{Ti}$ and $\mathrm{Ti}$ alloys in the non $-\mathrm{O}_{2}$ artificial saliva containing $0.2 \% \mathrm{NaF}(905 \mathrm{ppm} \mathrm{F})$. The fluoride concentration of widely used fluoride-containing dentifrices is about $1,000 \mathrm{ppm}$. The environment of the non- $\mathrm{O}_{2}$ artificial saliva containing $0.2 \% \mathrm{NaF}$ corresponds to the situation where the fluoride-containing dentifrice is used at an oral location with a 
low dissolved-oxygen concentration. It was shown that the Ti-0.2Pd and Ti-0.5Pt alloys maintained high corrosion resistances even in conditions at which the corrosion resistance of pure $\mathrm{Ti}$, and the $\mathrm{Ti}-6 \mathrm{Al}-4 \mathrm{~V}$ and $\mathrm{Ti}-6 \mathrm{Al}-7 \mathrm{Nb}$ alloys was lost.

Under the low dissolved-oxygen concentration conditions, the boundary $\mathrm{pH}$ values at which the corrosion behavior changed, shifted to higher $\mathrm{pH}$ values. For example, the corrosion resistance of pure $\mathrm{Ti}$ was maintained at a $\mathrm{pH}$ above 4.4 in the open-air $0.1 \% \mathrm{NaF}$ solution conditions (Fig. $4(\mathrm{a})$ ). However, the boundary $\mathrm{pH}$ value shifted to $\mathrm{pH} 5.2$ in the non- $\mathrm{O}_{2}$ conditions (Fig. 4(b)). Fig. 5 shows the diagram indicating the non-corrosive and corrosive regions of the fluoride concentrations and $\mathrm{pH}$ values in $\mathrm{Ti}$ and $\mathrm{Ti}$ alloys. This shows that corrosion resistance decreases under the non$\mathrm{O}_{2}$ environment. When the $\mathrm{NaF}$ concentration was $0.2 \%$, for example, the corrosion occurred at a $\mathrm{pH}$ below 5.0 in the Ti-6Al-4V under the open-air conditions. However, under the non $-\mathrm{O}_{2}$ conditions, the corrosion occurred at a $\mathrm{pH}$ below 5.7. Therefore, the Ti-6Al-4V and Ti-6Al-7Nb alloys were susceptible to fluoride in the low dissolvedoxygen concentration conditions and the corrosion occurred even at a $\mathrm{pH}$ value around neutrality. Even if the oxide film is broken by the presence of a little fluoride, it is suggested that the film immediately regenerates under the open-air environment at which the dissolved-oxygen is sufficient, and that the corrosion resistance is maintained. In contrast, under the low dissolved-oxygen concentration conditions, it will take more time or will not be able to regenerate the broken oxide film. At $\mathrm{pH}$ 4.0 , the amount of dissolved $\mathrm{Ti}$ in the $\mathrm{Ti}-0.2 \mathrm{Pd}$ and $\mathrm{Ti}-0.5 \mathrm{Pt}$ alloys was significantly $(\mathrm{p}<0.01)$ smaller than the pure Ti as shown in Fig. 6 and, therefore, they had a high corrosion resistance compared with pure Ti. Comparing the results under more corrosive conditions ( $\mathrm{pH} 3.4$ ), it can be seen that the Ti-0.5Pt alloy had a higher corrosion resistance than the $\mathrm{Ti}-0.2 \mathrm{Pd}$ alloy.

The corrosion resistance of titanium depends on the balance of a dissolution and a formation of a passive film. In the presence of fluoride, when the dissolved oxygen concentration is low, the reproduction of a passive film is delayed. It is suggested that the corrosion of titanium occurs because the balance shifts to the dissolution reaction of the passive film. The presence of $\mathrm{Pt}$ as well as $\mathrm{Pd}$ accelerated the cathodic reaction, and consequently, it was suggested that the corrosion potential of the alloy shifted into the passive region of $\mathrm{Ti}^{10,11}$. The corrosion potential of the alloy was more noble than the critical potential for passivation of $\mathrm{Ti}$. In these alloys, it was suggested that a reproduction of the passive film was promoted by the addition of $\mathrm{Pd}$ or $\mathrm{Pt}$, and the high corrosion resistance was maintained under the low dissolvedoxygen concentration environment. The Ti-0.2Pd and Ti-0.5Pt alloys are expected to be useful as new Ti alloys with high corrosion resistance in dental use.

\section{CONCLUSIONS}

This study examined the effects of various dissolved-oxygen concentrations and fluoride concentrations on the corrosion behaviors of commercial pure $\mathrm{Ti}$, and the Ti-6Al$4 \mathrm{~V}$ and $\mathrm{Ti}-6 \mathrm{Al}-7 \mathrm{Nb}$ alloys used presently in clinical dentistry and the experimentally 
produced Ti-0.2Pd and Ti-0.5Pt alloys.

1. A decrease in the dissolved-oxygen concentration tended to reduce the corrosion resistance of $\mathrm{Ti}$ and $\mathrm{Ti}$ alloys, but did not cause a severe corrosion of $\mathrm{Ti}$.

2 . Under low dissolved-oxygen conditions, the corrosion of pure $\mathrm{Ti}$ and $\mathrm{Ti}-6 \mathrm{Al}-$ $4 \mathrm{~V}$ and $\mathrm{Ti}-6 \mathrm{Al}-7 \mathrm{Nb}$ alloys might easily take place in the presence of a small amount of fluoride. Pure Ti, Ti-6Al-4V and Ti-6Al-7Nb alloys were corroded by half or less the fluoride concentrations currently found in commercial dentifrices (less than 453 ppm F).

3 . The experimentally produced Ti-0.2Pd and Ti-0.5Pt alloys did not corrode even under low dissolved-oxygen concentrations and fluoride-containing conditions. These alloys are expected to be useful as new $\mathrm{Ti}$ alloys with high corrosion resistance in dental use.

\section{ACKNOWLEDGEMENTS}

This study was supported by a Grant-in Aid for Scientific Research (12671892) from the Ministry of Education, Culture, Sports, Science and Technology, Japan.

\section{REFERENCES}

1) Lausmaa, J., Kasemo, B. and Hansson, S.: Accelerated oxide grown on titanium implants during autoclaving caused by fluorine contamination, Biomaterials $6: 23-27,1985$.

2) Boere, G.: Influence of fluoride on titanium in an acidic Environment measured by polarization resistance technique, J App Biomater 6 : 283-288, 1995.

3) Oda, Y., Kawada, E., Yoshinari, M., Hasegawa, K. and Okabe, T.: The influence of fluoride concentration on the corrosion of titanium and titanium alloys, $J J$ Dent Mater Dev 15 : 317-322, 1996. (in Japanese)

4) Mimura, H. and Miyagawa, Y.: Electrochemical corrosion behavior of titanium castings: Part 1 Effects of degree of surface polishing and kind of solution, $J J$ Dent Mater Dev $15: 283-295,1996$. (in Japanese)

5) Toumelin-Chemla, F., Rouelle, F. and Burdairon, G.: Corrosive properties of fluoridecontaining odontologic gels against titanium, J Dentistry 24 : 109-115, 1996.

6) Probster, L., Lin, W. and Hutteman, H.: Effect of fluoride prophylactic agents on titanium surface, Int $J$ Oral Maxillofac Implants 7:390-394, 1992.

7) Nakagawa, M., Matsuya, S., Shiraishi, T. and Ohta, M.: Effect of Fluoride Concentration and $\mathrm{pH}$ on Corrosion Behavior of Titanium for Dental Use, $J$ Dent Res 78(9):1568$1572,1999$.

8) Kononen, Mauno H. O., Lavonius, Eeva T. and Kivilahti, K.: SEM observations on stress corrosion cracking of commercially pure titanium in a topical fluoride solution, Dent Mater 11 : 269-272, 1995.

9) Mettraux, G. R., Gusberti, F.A. and Graf, H.: Oxygen tension $\left(\mathrm{pO}_{2}\right)$ in untreated human periodontal pockets, J. Periodontology 55(9): 516-521, 1984.

10) Morishita, M., Chikuda, M., Ashida, Y., Morinaga, M., Yukawa, N. and Adachi, H.: Correlation between Electronic States of the Cathodes and Hydrogen Overpotential for Titanium-based Alloys, J. Japan Inst Metals 55(6): 720-726, 1991. (in Japanese)

11) Watanabe, T. and Naito, H.: Corrosion Characteristics of a Ti-0.14 mass\% Pd Alloy in NaCl-HCl Solutions, J. Japan Inst Metals 52(8) : 780-785, 1988. (in Japanese)

12) Nakagawa, M., Matsuya, S. and Udoh, K.: Corrosion Behavior of Pure Titanium and Titanium Alloys in Fluoride-Containing Solutions, Dent Mater J 20(4) : 305-314, 2001. 